\title{
Human papillomavirus Type 16 infection of the cervix: a comparison of differing DNA detection modes and the use of monoclonal antibodies against the major capsid protein
}

\author{
C J N Lacey, M Wells, R I J Macdermott, P E Gibson
}

\begin{abstract}
An immuno-peroxidase technique using monoclonal antibodies against the major capsid protein L1 of HPV-16 was compared with dot-blot hybridisation of cervical scrapes and in situ hybridisation of cervical biopsy specimens for HPV-16 DNA. In a series of 20 patients all techniques were specific for HPV-16 infection. Ten patients were positive by dotblot hybridisation and half of those were positive by in situ hybridisation. Only one of HPV-16 DNA positive cases showed L1 protein expression, apparently shortly after the onset of clinical infection. Whether major capsid protein expression reflects episodes of viral replication deserves further study.
\end{abstract}

\section{Introduction}

Infection with certain specific types of human papillomaviruses (HPV) has emerged as a necessary, but not sufficient factor, in the genesis of anogenital cancer. HPV 16 is the most prevalent genital genotype and there is strong supportive evidence for its causal role in a large proportion of cervical neoplasms. ${ }^{1}$ HPV-DNA can be detected by DNA-DNA hybridisation using a variety of methods including Southern blotting, dot-blot, filter in situ hybridisation, tissue in situ hybridisation or the polymerase chain reaction. ${ }^{2}$ However, until very recently it has

Department of Genitourinary Medicine, General Infirmary, Leeds LS1 3EX

C J N Lacey, R I J Macdermott

Department of Pathology, University of Leeds, Leeds LS2

$M$ Wells

Virus Reference Laboratory, Central Public Health Laboratory, London NW9 5HT, UK

PE Gibson not been possible to produce type-specific antibodies because of the lack of replication of HPV in tissue culture and the low amounts of viral DNA present in genital lesions. These difficulties have now been overcome by the cloning in bacterial vectors of sequences of individual open reading frames of differing HPV types and the production of fusion proteins. ${ }^{3}$ The availability of a series of monoclonal antibodies against the major capsid protein $\mathrm{Ll}$ of HPV type $16^{4}$ prompted us to compare two differing HPV-DNA detection modes with immunohistochemistry for the L1 protein in the diagnosis of HPV 16 infection of the cervix.

Methods

Subjects and procedures

Twenty women were selected for further study from a cohort of women undergoing diagnostic colposcopic examination for the presence of cervical intraepithelial neoplasia in a genitourinary medicine/ sexually transmitted disease clinic. Subjects were routinely screened at initial presentation for genital tract infection and with cervical cytology. Criteria for colposcopic examination included cytological dyskaryosis or clinical suspicion of a cervical lesion on macroscopic inspection. At the beginning of the colposcopic examination a cervical scrape was performed with an Ayre's spatula. These exfoliated cells were screened for the presence of HPV 6/11, 16, 18 and 31 DNA by dot-blot hybridisation. Colposcopy was performed in a standard manner and directed cervical biopsies were taken from areas of maximal colposcopic abnormality within the transformation zone and placed in neutral buffered formalin. Further studies were performed on cervical biopsy specimens from 20 women, ten known to be HPV-16 DNA positive by dot-blot hybridisation and ten negative for HPV 6/11, 16, 18 and 31 DNA by dot-blot hybridisation. Within these defined groups subjects were randomly selected on the basis of a generous cervical punch biopsy specimen. 


\section{Dot-blot hybridisation}

Specimens were digested with proteinase K $(200 \mathrm{mg} /$ $\mathrm{ml}$ in $10 \mathrm{mM}$ Tris $\mathrm{pH} \mathrm{7.4,} 10 \mathrm{mM} \mathrm{NaCl}, 10 \mathrm{mM}$ EDTA and $0.5 \% \mathrm{SDS}$ ) for 15 hours at $37^{\circ} \mathrm{C}$. DNA was extracted twice with an equal volume of phenol/ chloroform and once with chloroform/iso-amyl alcohol. All DNA extracts were precipitated overnight at $-20^{\circ} \mathrm{C}$ with one tenth volume of $5 \mathrm{M} \mathrm{NaCl}$ and two volumes of ethanol. Precipitates were washed with $80 \%$ ethanol, repelleted, dried briefly under vacuum and resuspended in TE buffer $(10 \mathrm{mM}$ Tris $\mathrm{pH} 7 \cdot 4,1 \mathrm{mM}$ EDTA). The DNA content of each was determined using a TKO 100 minifluorometer (Hoefer Scientific Instruments).

The HPV 6, 11, 16 and 18 clones were gifts from Dr $\mathbf{H}$ zur Hausen and Dr L Gissmann (Deutsches Krebsforschungzentrum, Heidelberg) and HPV 31 a gift from Dr A Lorincz (Bethesda Research Laboratories, Maryland, USA). After transfection and amplification in Escherichia coli, the clones were extracted and then purified away from the flanking vector sequences by agarose gel electrophoresis and elution. ${ }^{5}$ Inserts were labelled by nick translation with $\left({ }^{32} \mathbf{P}\right) \mathrm{dCTP}$ and the probes were used at approximately $10^{6} \mathrm{cpm} / \mathrm{ml}$ (final concentration) in the hybridisation mixture.

The DNA samples were each divided into two aliquots, denatured with $\mathrm{NaOH}$ (final concentration $0.3 \mathrm{~N}$ ) for $\frac{1}{2}$ to 1 hour and spotted onto duplicate prewetted Hybond-N nylon membranes (Amersham International, UK) using a manifold (Schleicher and Schnell, Germany). Purified DNAs (10 pg and 100 pg amounts) of all five HPV types under investigation and of the plasmid vector were included as controls. The samples were neutralised on the membranes with $200 \mu$ l of $1.5 \mathrm{M} \mathrm{NaCl}, 0.5 \mathrm{M}$ Tris, $\mathrm{pH} 7 \cdot 4$.

The duplicate membranes were prehybridised in a solution containing $6 \times$ SSC, $5 \times$ Denhardt's solution, $0.5 \% \mathrm{SDS}$, and $100 \mathrm{mg} / \mathrm{ml}$ salmon sperm DNA at $65^{\circ} \mathrm{C}$ for $2-4$ hours. Hybridisation was carried out overnight with HPV 11 and 16 probes first. Membranes were washed twice with $2 \times$ SSC for 15 minutes, once with $2 \times$ SSC containing $0.1 \%$ SDS for 30 minutes, and once with $0 \cdot 1 \% \times$ SSC for 10 minutes, each wash being done at $65^{\circ} \mathrm{C}$. The membranes were exposed at $-70^{\circ} \mathrm{C}$ to $\mathrm{X}$-ray film (Amersham MP Hyperfilm) for 1-7 days. The probes were stripped from the membranes with $0.4 \mathrm{M}$ $\mathrm{NaOH}$ at $45^{\circ} \mathrm{C}$, the membranes were neutralised with a buffer containing $0.1 \times$ SSC, $0.1 \%$ SDS, and $0.2 \mathrm{M}$ Tris- $\mathrm{HCl}, \mathrm{pH} \mathrm{7 \cdot 5}$, and then reprobed with HPV 18 and 31.

Although these highly stringent dot-blot conditions did not differentiate between HPV types 6 and 11 (which are very closely related) no other crossreactions were observed among the five HPV types used. The conditions detected $<10 \mathrm{pg}$ of control DNA.

\section{In situ hybridisation}

Pre-treatment: Paraffin wax embedded tissue specimens were sectioned at 3-5 $\mu \mathrm{m}$ and placed on 3amine propyl triethoxysilane coated single well shades and hotplated to ensure maximum tissue adhesion. Sections were dewaxed in xylene at $37^{\circ} \mathrm{C}$ for 30 minutes, xylene at room temperature for 10 minutes, and absolute alcohol twice for 10 minutes. The sections were hydrated through a series of graded alcohols to distilled water and immersed in phosphate buffered saline for five minutes. The slides were transferred to $0.2 \mathrm{M} \mathrm{HCl}$ for 10 minutes, incubated in $0.1 \%$ Triton $\mathrm{X}-100$ for three minutes to permeabilise membranes, and digested with proteinase $\mathrm{K}$ for 15 minutes at $37^{\circ} \mathrm{C}$ to access the cellular DNA. After washing in several changes of phosphate buffered saline the slides were placed in $20 \%$ acetic acid in water at $4^{\circ} \mathrm{C}$ for 15 seconds to destroy endogenous tissue alkaline phosphatase and postfixed in $4 \%$ paraformaldehyde before dehydration through graded alcohols to $100 \%$ ethanol.

Hybridisation: The DNA probe used was HPV 16 linked to the plasmid PBR 322. It was biotinylated with biotin-II-dUTP using a nick translation kit (Gibco-BRL, High Wycombe, Buckinghamshire). The biotinylated probes were prepared at a concentration of $200 \mathrm{ng} / \mathrm{ml}$ in a hybridisation buffer containing $2 \times$ SSC, $5 \%$ dextran sulphate, $0.2 \%$ dried milk powder, $50 \%$ formamide $(1 \times$ SSC $=$ $0.15 \mathrm{M}$ sodium chloride, $0.015 \mathrm{M}$ sodium citrate).

Hybridisation mixture (75 $\mu$ l) (12 ng DNA probe) was added to each prepared section, the well was covered with a piece of Gel Bond (ICN Biochemicals, Paisley, Scotland) hydrophobic side down, and sealed with nail varnish. Cellular and probe DNA were made single stranded by heating the slides at $90^{\circ} \mathrm{C}$ for 10 minutes, and hybridisation was carried out overnight at $42^{\circ} \mathrm{C}$.

Detection of hybridisation signal: After removing the Gel Bond cover slip the slides were immersed in $30 \%$ bovine serum albumin for five minutes to block all non-specific streptavidin binding sites in the tissue. Streptavidin was then added to each slide and incubated for 20 minutes. The slides were washed free of excess streptavidin and incubated with biotinylated alkaline phosphatase to react with the remaining biotin binding sites on the bound streptavidin. The alkaline phosphatase was detected by reaction with a substrate containing nitroblue tetrazolium and 5-bromo-4-chloro-3 indolyl phosphate to produce a purple blue precipitate at the site of hybridisation. The slides were then counterstained with methyl green. A positive control of total human DNA and two negative controls of PBR 322 without probe and hybridisation buffer alone were also carried out. The full technique has been reported in detail elsewhere. ${ }^{6}$

Immunohistochemistry

Four monoclonal antibodies to the LI gene product 
Table 1 Characteristics of the study population

\begin{tabular}{|c|c|c|}
\hline & $\begin{array}{l}\text { Dot-blot } \\
H P V 16+v e \\
(n=10)\end{array}$ & $\begin{array}{l}\text { Dot-blot } \\
H P V 16-v e \\
(n=10)\end{array}$ \\
\hline $\begin{array}{l}\text { Mean age (standard deviation) } \\
\text { Clinical genital warts } \\
\text { Cytologic dyskaryosis } \\
\text { Histologic intra-epithelial } \\
\text { neoplasia } \\
\text { CIN II or III }\end{array}$ & $\begin{array}{l}22 \cdot 3(5 \cdot 2) \\
5 \\
8 \\
8 \\
5\end{array}$ & $\begin{array}{l}26 \cdot 5(5 \cdot 1) \\
5 \\
5\end{array}$ \\
\hline
\end{tabular}

of HPV 16 were employed designated 1C6, 3D1, 5A4, 8C4 (prepared by Dr P S Shepherd and Dr D J McCance, United Medical \& Dental Schools, Guy's Hospital, University of London).

Sections were labelled by a streptavidin-biotinperoxidase technique (ICN Immunobiologicals, High Wycombe, Bucks). All steps were performed at room temperature and followed by two brief washes in 0.05 M Tris buffered 0.15 M saline, pH 7.6 (TBS). Briefly, paraffin sections were dewaxed, and treated with methanol containing $0 \cdot 2 \%(\mathrm{v} / \mathrm{v}) \mathrm{H}_{2} \mathrm{O}_{2}$ to block endogenous peroxidase activity. Sections were incubated with the appropriate antibody diluted 1:5 in TBS. The sections were then incubated sequentially with biotinylated antimouse immunoglobulins and streptavidin-peroxidase for $10 \mathrm{~min}$ and $5 \mathrm{~min}$, respectively, per the suppliers instructions. Finally the peroxidase reaction was developed in a $0.025 \%$ $(\mathrm{w} / \mathrm{v})$ solution of diaminobenzidine in TBS containing $0.01 \%(\mathrm{v} / \mathrm{v}) \mathrm{H}_{2} \mathrm{O}_{2}$ and slides were counterstained with methyl green, dehydrated and mounted in DPX. For each specimen, a negative control was included in which the primary monoclonal antibody was replaced by TBS.

\section{Results}

The two groups of women who were HPV type 16 DNA positive and negative, respectively, were broadly comparable in terms of age, presence of genital warts, dyskaryosis and intra-epithelial neoplasia (table 1). Neither was there any difference in the spectrum of grading of intra-epithelial neoplasia between the two groups:

Table 2 Comparison of dot-blot for HPV-16 DNA, in situ hybridisation for HPV-16 DNA, and immunohistochemistry for $H P V-16 L 1$

\begin{tabular}{lll}
\hline & $\begin{array}{l}\text { Dot-blot } \\
H P V 16+v e \\
(=10)\end{array}$ & $\begin{array}{l}\text { Dot-blot } \\
H P V 16-v e \\
(n=10)\end{array}$ \\
\hline $\begin{array}{c}\text { In situ hybridisation + ve } \\
\text { for HPV-16 DNA }\end{array}$ & 5 & 0 \\
$\begin{array}{c}\text { Immunohistochemistry + ve } \\
\text { for HPV-16 L1 }\end{array}$ & 1 & 0 \\
\hline
\end{tabular}

The total quantity of DNA extracted from exfoliated cervical cells was also similar in the two groups with a range of 3.4-69.3 $\mu \mathrm{g}$ and a mean of $29 \cdot 7$ $\mu \mathrm{g}$ in the HPV 16 positive women, compared to $11 \cdot 6-$ $73.0 \mu \mathrm{g}$ with a mean of $39.0 \mu \mathrm{g}$ in the HPV 16 negative women. The results of in situ hybridisation for HPV16 DNA and immunohistochemistry for the HPV 16 major capsid protein are shown in table 2 . None of the women who were negative by dot-blot hybridisation for HPV-16 DNA showed any reactivity by in situ hybridisation for DNA or immunohistochemistry for L1. However, of the HPV-16 dot-blot positive women five out of 10 were positive by in situ hybridisation. Four out of these five women showed relatively sparse, focal distribution of HPV-DNA and were negative by immunohistochemistry using monoclonals for the major capsid protein. However, one of the ten HPV-16 dot-blot positive women showed a strongly positive in situ hybridisation signal for HPV-16 DNA (fig 1) accompanied by specific expression in the upper one third of the epithelium of the major capsid protein (fig 2). Whereas antibodies $3 \mathrm{D} 1,8 \mathrm{C} 4$, and $5 \mathrm{~A} 4$ gave a strong reaction, antibody $1 \mathrm{C} 6$ only gave a weakly positive signal in this biopsy. Within the dot-blot HPV 16 positive women four of the five cases positive on in situ hybridisation had a CIN II/III lesion compared

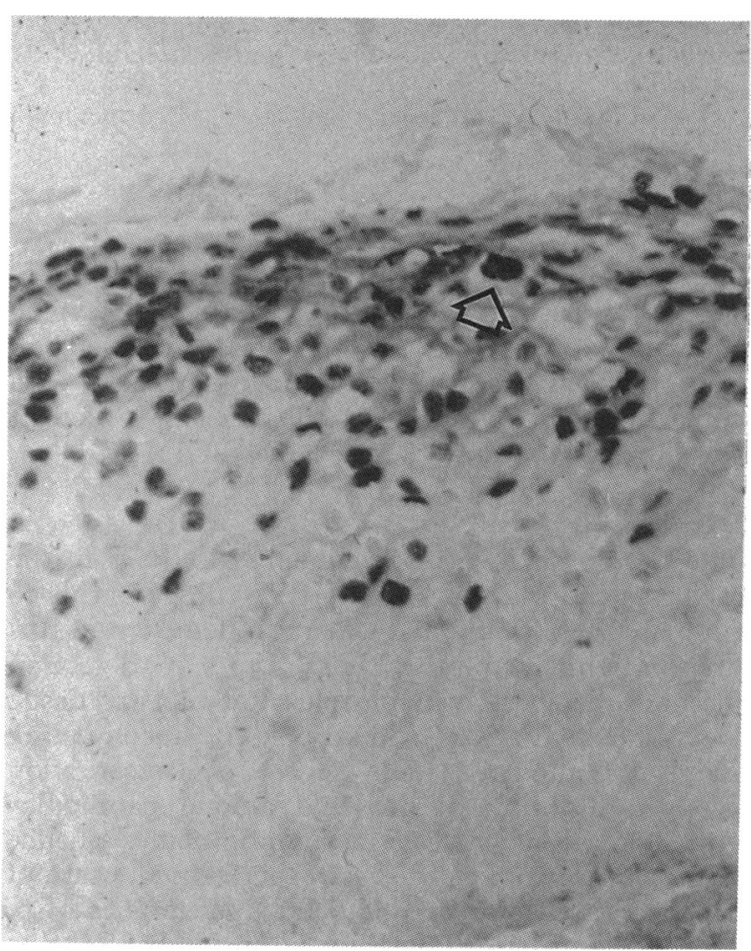

Fig $1 H P V-16$ DNA positive cervical biopsy by in situ hybridisation; arrow indicates dense nuclear reactivity in the superficial layer of the epithelium. 


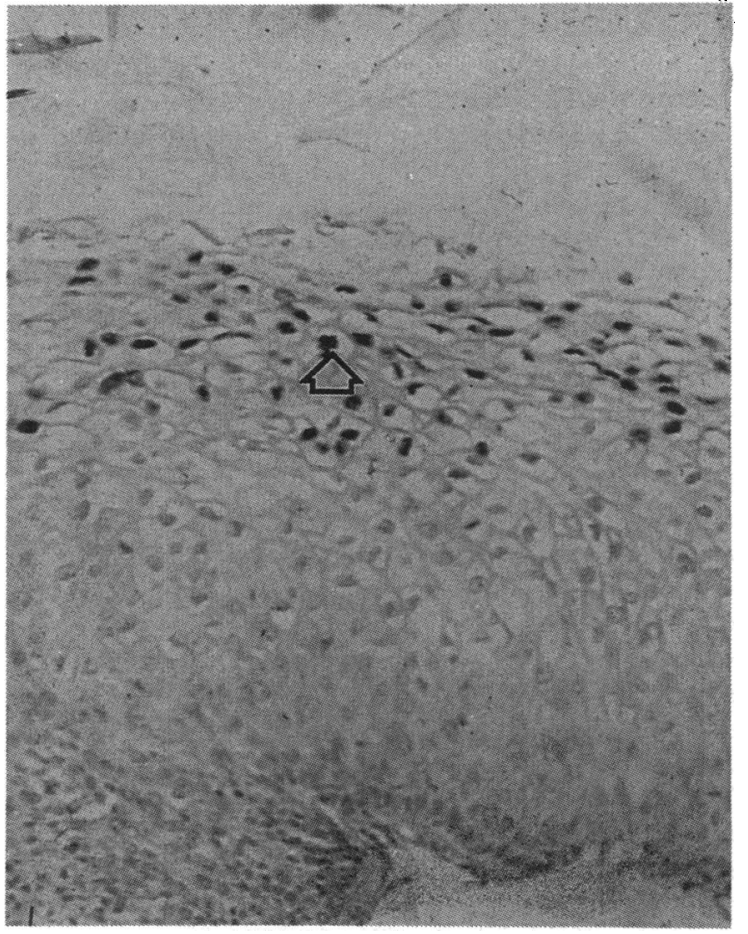

Fig 2 HPV-16 major capsid protein positive cervical biopsy by immunohistochemistry; arrow indicates positive immunoreactivity in a koilocyte in the superficial cervical epithelium.

with one of the five biopsy specimens negative on in situ hybridisation. The single biopsy specimen showing expression of the major capsid protein of HPV 16 was from an 18 year old female with concurrent chlamydial infection and a single lifetime sexual partner, whose biopsy showed CIN II.

\section{Discussion}

The development of monoclonal antibodies to the major capsid protein L1 of HPV type 16 led us to compare the immunohistochemical detection of this protein with two other HPV type 16 detection methods that were available to us, dot-blot and tissue in situ DNA-DNA hybridisation. The open reading frame L1 shows a high degree of conservation between differing human and animal papillomaviruses reaching $50 \%$ at the amino acid sequence level. ${ }^{7}$ Cason et al have performed careful experiments using the monoclonal antibodies $1 \mathrm{C} 6$, $8 \mathrm{C} 4,3 \mathrm{D} 1$ and $5 \mathrm{A4} .^{8}$ They showed antibody $8 \mathrm{C} 4$ to be specific for HPV-16, 1 C6 to be specific for HPV-16 on infected tissue sections, and antibodies 3D1 and 5A4 to recognise both HPV-2 and HPV-16 infected tissue sections. We chose women who were known to be HPV-16 positive or negative by dot-blot hybridisation to assess the sensitivity of the differing HPV-16 DNA detection modes and to investigate the presence of the $\mathrm{L} 1$ protein within cervical epithelium in HPV-16 infection. Whereas dot-blot hybridisation can detect one viral genome copy per cell provided sufficient cellular DNA is analysed, tissue in situ hybridisation using biotin labelling as in our experiments requires some cells to contain $200-800$ viral genomes. ${ }^{29}$ Considering that dot-blot hybridisation was performed on exfoliated cells from the transformation zone whereas in situ hybridisation could only be applied to areas of maximal colposcopic abnormality there was good agreement between these methods, with 5 in situ hybridisation positives from 10 dot-blot hybridisation positives. Schneider has demonstrated the regional distribution pattern of HPV-16 infection within the transformation zone 9 and our results are in keeping with this. There was a preponderance of high-grade intra-epithelial lesions within the in situ hybridisation positive biopsy specimens, perhaps reflecting the sensitivity of the biotin-labelling technique for the dense genome expression seen in CIN II and III. ${ }^{10}$ The sensitivity of the dot-blot hybridisation procedure was confirmed by the absence of any positives by in situ hybridisation in the control group.

Antibodies against papillomavirus capsid antigen prepared by detergent disruption of BPV-1 have been available for a number of years and detect a group-common epitope that has been mapped for HPV-16 to a 15 amino acid region on the L1 protein..$^{4}$ It should be remembered that monoclonal antibodies raised against a recombinant protein as used in this study will only detect linear epitopes and not necessarily epitopes on native proteins that are conformational or involve post-translational modifications. The monoclonal antibodies we used in the present study, have been shown to detect one third of biopsies positive by polyclonal cross-reacting antisera. ${ }^{4}$ It has previously been shown that only $9 \%$ of cervical specimens positive for HPV 16,18 or 31 DNA are antigen positive with polyclonal antisera $^{11}$ while $17 \%$ of HPV-16 positive ano-genital lesions are reactive. ${ }^{12}$ Thus in our experiments the one biopsy positive with monoclonal antibodies against $\mathrm{L} 1$ from ten dot-blot hybridisation positives or five in situ hybridisation positives is in keeping with these published data. The significance of the demonstration of $\mathrm{Ll}$ protein production within HPV-16 cervical infection is not yet clear but it is of interest that this was shown in one of the youngest patients in the study with strong clinical evidence of a recent primary sexually transmitted infection. Whether capsid antigen production might reflect one, or particular events, within HPV-16 infection deserves further investigation. 
We are grateful to $\mathrm{Dr} \mathrm{J} \mathrm{H}$ Kennedy, British Technology Group for making available to us the monoclonal antibodies prepared at UMDS, Guy's Hospital, London, by Drs Shepherd and McCance.

CJNL, RIJMcD and MW gratefully acknowledge the support of the Yorkshire Cancer Research Campaign.

\section{Address correspondence to Dr Lacey.}

1 zur Hausen H. Papillomaviruses in anogenital cancer as a model to understand the role of viruses in human cancers. Cancer Res 1989;49:4677-81.

2 Lancaster WD, Norrild B. Diagnosis of HPV by DNA hybridization techniques. In: Munoz N, Bosch FX, Jensen OM, eds. Human Papillomavirus and Cervical Cancer. Lyon: IARC Scientific Publications No 94, 1989:87-103.

3 Banks L, Matlashewski G, Pim D, Churcher M, Roberts C, Crawford L. Expression of human papillomavirus type 6 and type 16 capsid proteins in bacteria and their antigenic characterization. J Gen Virol 1987;68:3081-9.

4 Patel D, Shepherd PS, Naylor JA, McCance DJ. Reactivities of polyclonal and monoclonal antibodies raised to the major capsid protein of human papillomavirus type 16. J Gen Virol 1989;70:69-77.
5 Maniatis T, Fritsch EF, Sambrook J. Molecular Cloning, a Laboratory Manual. Cold Spring Harbor, New York, 1982.

6 Lewis FA, Griffiths S, Dunnicliff R, Wells M, Dudding N, Bird CC. Sensitive in situ hybridisation technique using biotinstreptavidin-polyalkaline phosphatase. J Clin Pathol 1987; 40:163-6.

7 Pfister H, Fuchs PG. Papillomaviruses: particles, genome organization and proteins. In: Syrjanen K, Gissmann L, Koss LG, eds. Papillomaviruses and Human Disease. Berlin: SpringerVerlag, 1987:1-18.

8 Cason J, Patel D, Naylor J, et al. Identification of immunogenic regions of the major coat protein of human papillomavirus type 16 that contain type-restricted epitopes. J Gen Virol 1989;70:2973-87.

9 Schneider A. Methods of identification of human papillomaviruses. In: Syrjanen K, Gissman L, Koss LG, eds. Papillomaviruses and Human Disease. Berlin: Springer-Verlag, 1987:19-39.

10 Schneider A, Oltersdorf T, Schneider V, Gissmann L. Distribution pattern of human papillomavirus 16 genome in cervical neoplasia by molecular in situ hybridisation of tissue sections. Int J Cancer 1987;39:717-21.

11 Kiviat NB, Koutsky LA, Paavonen JA, et al. Prevalence of genital papillomavirus infection among women attending a college student health clinic or a sexually transmitted disease clinic. J Infect Dis 1989;159:293-302.

12 Syrjanen SM, von Krogh G, Syrjanen KJ. Detection of human papillomavirus DNA in anogenital condylomata in men using in situ DNA hybridisation applied to paraffin sections. Genitourin Med 1987;63:32-9.

Accepted for publication 13 December 1990 